\title{
Exosomes: New players in cancer (Review)
}

\author{
WEI GUO, YIBO GAO, NING LI, FEI SHAO, CHUNNI WANG, \\ PAN WANG, ZHENLIN YANG, RENDA LI and JIE HE

\begin{abstract}
Department of Thoracic Surgery, National Cancer Center/Cancer Hospital, Chinese Academy of
Medical Sciences and Peking Union Medical College, Chaoyang, Beijing 10021, P.R. China
\end{abstract}

Received December 30, 2016; Accepted May 29, 2017

DOI: 10.3892/or.2017.5714

\begin{abstract}
The past decade has witnessed an exponential increase in research on exosomes. For many years considered to be extracellular debris, exosomes are now considered important mediators in intercellular communication. The capability of exosomes to transfer proteins, DNA, mRNA, as well as non-coding RNAs has made them an attractive focus of research into the pathogenesis of different diseases, including cancer. Increasing evidence suggests that tumor cells release a large sum of exosomes, which may not only influence proximal tumor cells and stromal cells in local microenvironment, but also can exert systemic effects when participating in blood circulation. In this study, we review the current understanding on this topic. The literature outlines two broad facets of exosomes in cancer: 1) promotion of tumor growth, tumorigenesis, tumor angiogenesis, tumor immune escape, drug resistance, and metastasis and 2) their role as promising biomarkers for cancer diagnosis and even as potential treatment targets for cancer patients.
\end{abstract}

\section{Contents}

1. Introduction

2. Biogenesis, secretion, and uptake of exosomes

3. Contents of exosomes

4. Biological function of exosomes in cancer

5. Exosomes as cancer biomarkers

6. Exosomes as cancer therapeutic targets

7. Conclusion

Correspondence to: Dr Yibo Gao or Professor Jie He, Department of Thoracic Surgery, National Cancer Center/Cancer Hospital, Chinese Academy of Medical Sciences and Peking Union Medical College, 17 Panjiayuan Nanli, Chaoyang, Beijing 10021, P.R. China E-mail: gaoyibo@cicams.ac.cn

E-mail: prof.hejie@263.net

Key words: exosomes, cancer, function, biomarkers, therapeutic targets

\section{Introduction}

In recent years, the function of exosomes has evoked increased interest, particularly in cancer research. Described to harbor and deliver functional molecules to recipient cells, exosomes seemingly add a new layer of complexity to our understanding of molecular biology in multicellular organisms.

The definition of exosomes has evolved over time; the term was coined by Trams et al to describe the release of extracellular vesicles (EVs) with 5'-nucleotidase activity from various normal and neoplastic cell lines (1). In the late 1980s, the usage of the term was adapted to describe small vesicles of endosomal origin that are released during reticulocyte differentiation following the fusion of multivesicular bodies (MVBs) with the plasma membrane (2). Initially ascribed a cell-scavenging function, exosomes are now known to perform a much wider range of biological functions (3-5). However, since exosomes are difficult to discriminate and purify from EVs of other origins, several EV-induced functions reported in the literature may not necessarily be attributable to exosomes alone.

Exosomes are small, lipid bilayer membrane vesicles (30-100 nm) derived from the luminal membrane of multivesicular bodies (MVBs), which are constitutively released by fusion with the cell membrane (6-10). In this review, we highlight the recent advances in our understanding of the biological and functional role of exosomes in cancer, with an emphasis on the potential use of exosomes as biomarkers and therapeutic agents.

\section{Biogenesis, secretion, and uptake of exosomes}

Biogenesis of exosomes initiates as an endocytic event at the plasma membrane. The mechanisms by which exosomes sort their cargo into the MVBs are not yet fully understood. The best-described mechanism for exosome biogenesis is driven by the endosomal sorting complex required for transport (ESCRT) and the multimolecular machinery is recruited to the endosomal membrane where the individual steps of the exosome biogenesis are orchestrated (11). The second pathway of MVB formation is independent of the ESCRT machinery and is based on the specific lipid composition of the endosomal membrane. It has been reported that ceramides were involved in exosomes biogenesis $(12,13)$. Moreover, formation of MVBs has also been shown to be controlled by the syndecan heparin sulfate proteoglycans and their cytoplasmic adaptor syntenin (14). 

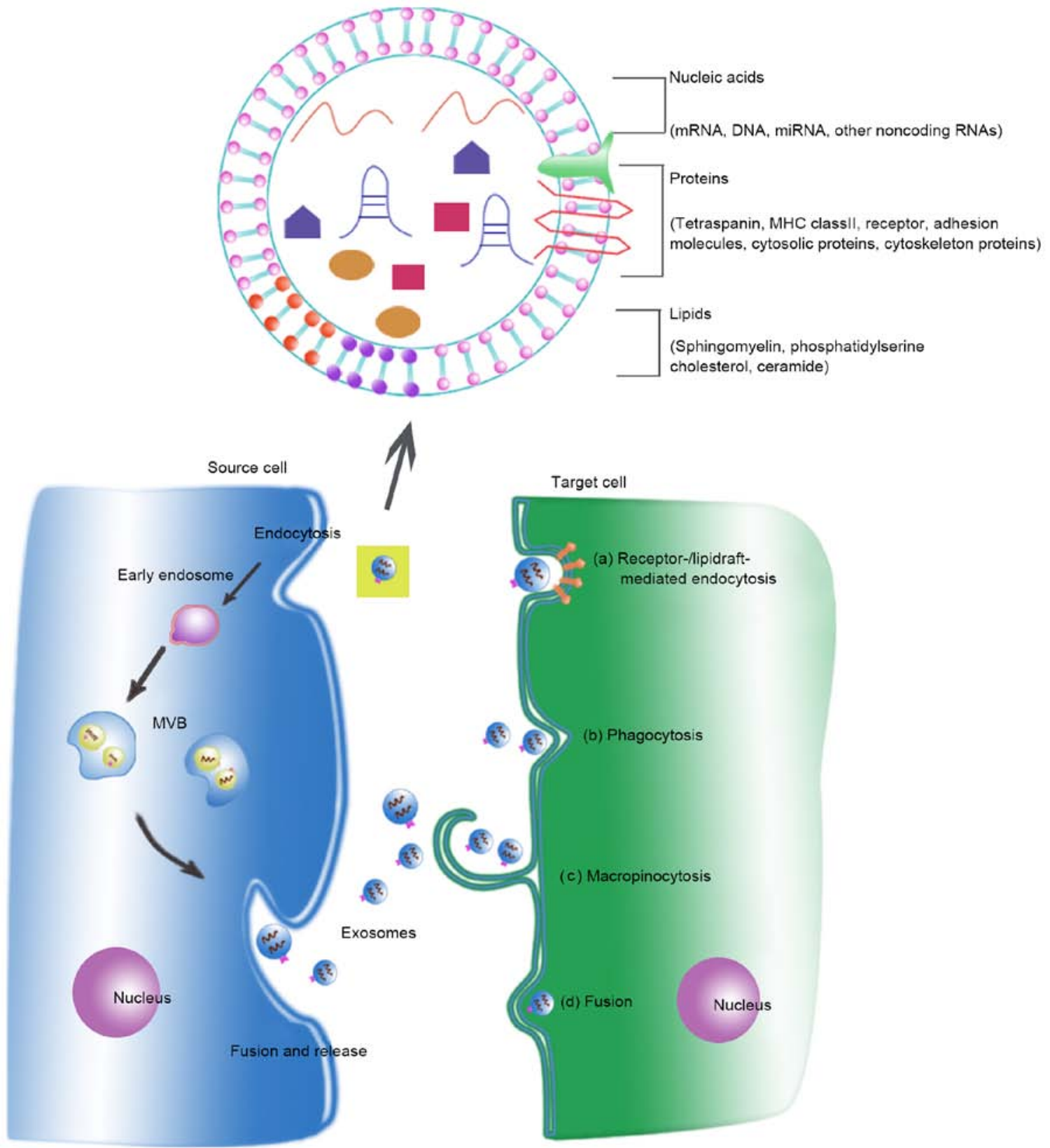

Figure 1. Biogenesis, release, content and uptake of exosomes. Early endosome is formed from the plasma membrane via endocytic pathway. MVB can be formed by the invagination of endosomal membrane. Dependent on the function and content, MVB then can be directed to fuse with plasma membrane and release to the extracellular space as exosomes. During the biogenesis of exosomes and prior to their secretion, proteins (e.g., tetraspanin, cytosolic proteins, receptor), nucleic acids (e.g., mRNA, miRNA, DNA), and lipids (e.g., sphingomyelin, cholesterol) are uploaded to exosomes. Cells appear to take up exosomes via several ways: (a) receptor-/lipidraft medated endocytosis, (b) phagocytosis, (c) macropinocytosis, (d) fusion with the plasma membrane of the target cell. MVB: multivesicular body.

Following the formation of MVBs, Rab GTPases govern their degradation as well as their secretion $(13,15)$. The final release of exosomes occurs upon fusion of MVBs with the cellular plasma membrane, a process which is probably mediated, at least in part, by soluble $\mathrm{N}$-ethylmaleimide-sensitive factor attachment protein receptors (SNAREs) (16). Furthermore, there is evidence that enhanced expression of p53, Pyruvate kinase type M2 (PKM2) and tumor suppressor-activated pathway 6 (TSAP6) upregulates the secretion of exosomes in tumor cells (17-19). Of note, the accumulation of intracellular $\mathrm{Ca}^{+}$and change in microenvironmental $\mathrm{pH}$ have been shown to affect the secretion of exosomes $(20,21)$.
Cells appear to take up exosomes by several molecular mechanisms. Most experimental evidence suggested that exosomes are internalized into recipient cells via endocytosis $(22,23)$. Endocytosis is a general statement for a range of molecular pathways, including calthrin-mediated endocytosis, coveolin-mediated endocytosis, phagocytosis and macropinocytosis (24-26). Moreover, the uptake of exosomes by direct cell surface membrane fusion has also been studied. Palolini et al demonstrate that at least a part of exosomes are able to fuse with the recipient cells directly and low $\mathrm{pH}$ facilitates this process (21). Additionally, there is also evidence to support the role of lipid rafts in exosome 


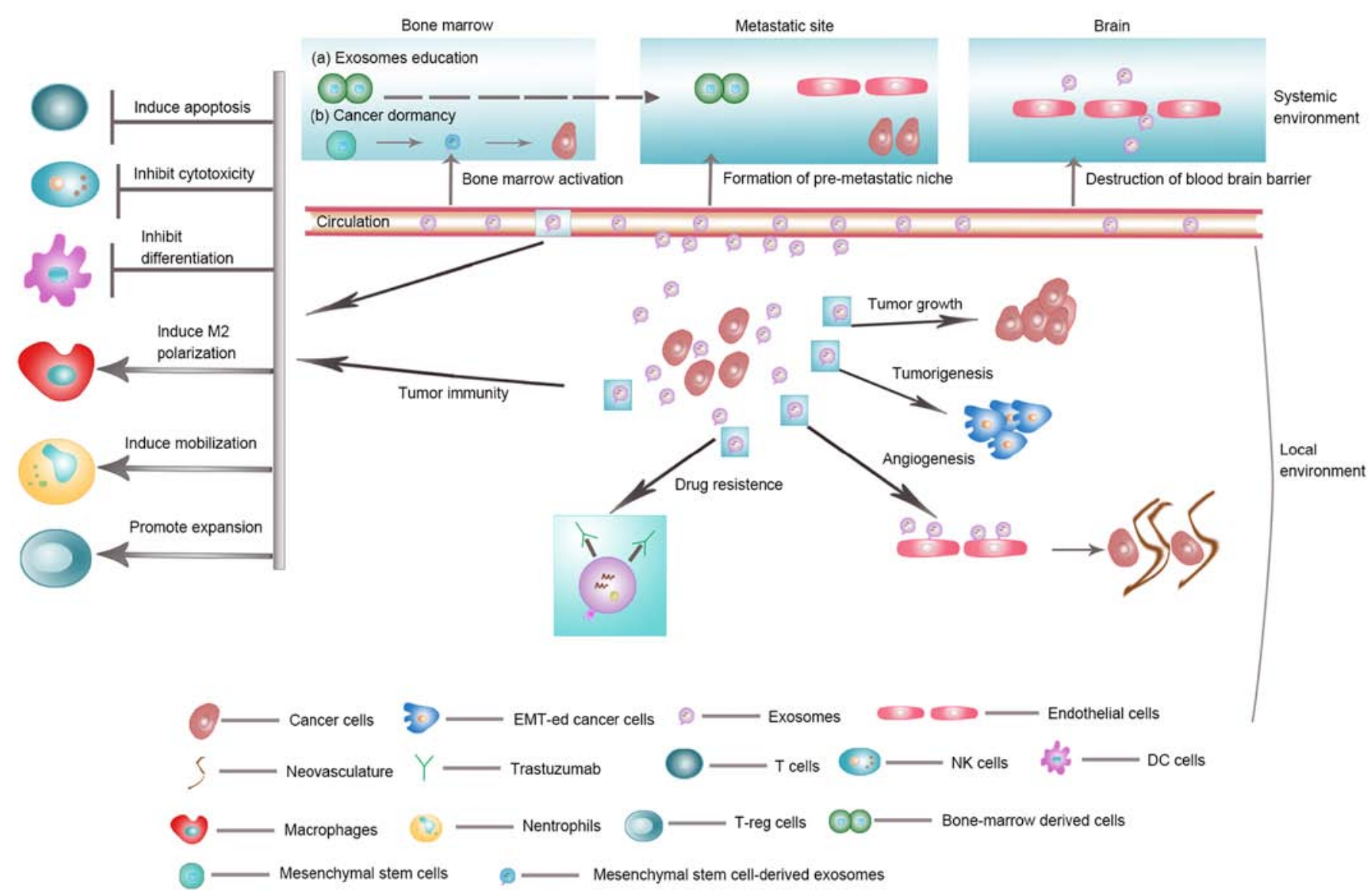

Figure 2. Biological function of exosomes in cancer. Exosomes are involved in tumor growth, tumorigenesis, angiogenesis, tumor immune escape, drug resistance and metastasis. EMT, epithelial-mesenchymal transition.

internalization $(27,28)$. Noteworthy, several research groups have shown that the uptake of exosomes by recipient cells is an energy-dependent process. For instance, the internalization of exosomes by ovarian cancer cells via several endocytic pathways were strongly inhibited at $4^{\circ} \mathrm{C}$ (24). Fig. 1 summarizes the complicated process of biogenesis, release, content and uptake of exosomes.

\section{Contents of exosomes}

During the biogenesis of exosomes and prior to their secretion, various molecules are uploaded into the lumen of exosomes. Exosomes contain several types of biomolecules, including lipids, proteins and nucleic acids (6) (Fig. 1). The exosomal content is heterogeneous and in a dynamic state, depending on the cell's origin, its physiological and pathological state, and even on the cellular release site (29).

When comparing exosomes with the total cell membranes, several studies observed that exosomes have a higher expression of sphingomyelin, cholesterol, phosphatidylserine, and generally of saturated fatty acids (6). The protein content in exosomes includes endosomal, plasma, and nuclear proteins (30). Proteins enriched in exosomes include those relevant for individual exosomal biogenesis pathways and for exosome secretion (31). Factors found in exosomes of different cell types include: TSG101, Alix, Rab GTPases, heat shock proteins (HSP70, HSP90), integrins, tetraspanins (CD9,
CD63, CD81) and MHC class II proteins (6). A number of reviews have described the protein and lipid composition of exosomes, and various databases, including ExoCarta (http:// www.exocarta.org/) and Vesiclepedia (http://microvesicle. org/), have cataloged the protein, lipid, and RNA content of exosomes $(32,33)$. In addition, exosomes can contain genetic material such as mRNA, long noncoding RNA (lncRNA), microRNA (miRNA) and even double-stranded DNA (34-36). Moreover, the composition of exosomes can be different from the cells of their origin due to the selective sorting of cargo into exosomes. However, not much is known about these selective shuttling mechanisms.

\section{Biological function of exosomes in cancer}

Emerging evidence suggests that exosomes derived from cancer cells are involved in tumor growth, tumorigenesis, angiogenesis, tumor immune escape, drug resistance and metastasis. Exosomes are also involved in the intercellular communication between cancer cells and stromal cells, especially with cancer-associated fibroblasts (CAFs). In this section, we reviewed recently published articles reporting the roles of exosomes in cancer and their underlying molecular mechanisms (Fig. 2).

Tumorigenesis. Exosomes derived from malignant cells have shown the potential to induce cell transformation. They can 
also affect other cells in the heterogeneous tumor population, and be involved in the transfer of metastatic capacity. For instance, exosomes released by malignant breast cancer cells are taken up by less malignant tumor cells located within the same tumor, and thereby promote their migratory and metastatic potential (37).

In addition, exosomal miRNA from cancer cells can contribute to tumorigenesis. Both mature miRNA and premiRNA transcripts are present in exosomes along with other key components of the machinery for miRNA biogenesis such as DICER, TRBP, and AGO2 (35). Melo et al demonstrated that exosomes derived from breast cancer cells and sera of patients with breast cancer could instigate nontumorigenic epithelial cells to form tumors (35). Although much of the evidence has emanated from in vitro studies, the exchange of exosomes between tumor cells was recently demonstrated in vivo in a study which combined high-resolution imaging with a Cre-LoxP system. Exosomes derived from malignant breast cancer cells are taken up by less malignant tumor cells within the same tumor and distant tumors. The mRNA content in the exosomes promotes migratory behavior and metastatic capacity of the recipient cancer cells (38).

CAFs are major components of the tumor microenvironment. Exosomes derived from CAFs can mediate horizontal transfer of miRNAs and proteins to affect breast cancer progression $(39,40)$. Webber et al demonstrated exosomal TGF- $\beta 1$ participated in the activation of myofibroblast, which is a rate-limiting step in cancer progression (41). Hoshino et al reported the effect of cancer cell-derived exosomes on multiple steps of invadopodia life cycle, including invadopodia formation and stabilization. Release of exosomal proteinases were also shown to enhance degradation of extracellular matrix (ECM) associated with invadopodia maturation (42). By inducing ECM degradation, cancer cell-derived exosomes promote tumor cell invasiveness and motility. Of note, Lazar et al showed that adipocytes secrete exosomes in abundance, which are then taken up by tumor cells, leading to increased migration and invasion (43). Collectively, these findings point towards a role of exosomes in tumorigenesis.

Tumor growth. The effect of tumor-derived exosomes on tumor growth has been widely reported in the past decade. Exosomes from sera of glioblastoma patients are enriched with EGFRvIII mRNA. The proliferation potential of recipient cells was shown to be greatly enhanced on co-culture with EGFRvIII-containing exosomes (44). Peinado et al demonstrated that melanoma exosomes containing MET oncoprotein can support tumor growth as well (4). In colorectal cancer, tumor-derived exosomes are enriched in cell cycle-related mRNAs, promoting proliferation of endothelial cells and tumor growth (45). Another study by Kogure et al showed that exosomes derived from hepatocellular carcinoma (HCC) cells can modulate TAK1 expression and associated signaling pathways to enhance cell growth in recipient cells (46). In addition, exosomes from stromal cells can promote proliferation through other signaling pathways $(47,48)$. For instance, $\mathrm{Au}$ Yeung et al demonstrated that CAF secreted exosomes to regulate survival and proliferation of pancreatic cancer cells, thus may serve as a potential target for overcoming resistance of chemotherapy. Similarly, miRNA-21 enriched in CAF exosomes may profoundly impact ovarian cancer growth by suppressing apoptosis through binding to APAF1 (49). Zhang et al reported that the loss of exosomal miRNA-320a from CAFs contributed to HCC proliferation (50).

While the majority of research evidence pertains to the pro-tumorigenic effect of tumor-derived exosomes, it is important to remember that the function of stromal-derived exosomes may differ from, and, perhaps, be opposite to that of cancer exosomes. The presence of a competitive biological process was well-characterized in multiple myeloma (MM). Bone marrow mesenchymal stromal cells (BM-MSCs) from patients with $\mathrm{MM}$ were shown to have a high expression of oncogenic proteins, which facilitated the growth of MM cells in vivo (51). In contrast, the level of miRNA-15a, a known suppressor of MM growth (52), was significantly higher in exosomes derived from BM-MSCs of normal individuals, thus suggesting a tumor suppressive role of MSC-derived miRNA-15a. Thus, exosomes from cancer and stromal cells may modulate tumor growth.

Angiogenesis. Angiogenesis is a fundamental physiological process involved in wound healing and carcinogenesis. Angiogenesis involves a close interaction between endothelial cells and their surrounding microenvironment. Uptake of exosomes by the endothelial cells (ECs) stimulates angiogenesis. Several groups reported the pro-angiogenic effect of tumor-derived exosomes on endothelial cells in various types of cancers such as glioblastoma, leukemia, multiple myeloma, melanoma, ovarian cancer and breast cancer (53-57). In a study by Skog et al, angiogenic-protein rich exosomes released from glioblastoma tumor cells were shown to stimulate tubule formation in ECs (53). Gopal et al demonstrated communication between oncogenic cells undergoing epithelial-mesenchymal transition (EMT) and endothelial cells via exosomes containing Rac1/PAK2 proteins as the angiogenic promoters (58).

Some miRNAs found in exosomes are thought to be specifically involved in tumor angiogenesis (59). For example, in colorectal cancer, miRNA-9 in tumor-derived exosomal vesiculars showed pro-angiogenic effects through inhibiting the expression of suppression of cytokine signaling 5 (SOCS5), promoting the migration of endothelial cells. In addition, miRNA-210 has been observed to suppress the expression of specific genes in endothelial cells, resulting in enhanced pro-angiogenic activity (60-62). Despite the direct pro-angiogenic effect of tumor-derived exosomes on endothelial cells, tumor-derived exosomes also demonstrated indirect effects on other stromal cells, such as CAFs. For example, in leukemia, tumor-derived exosomes induced a CAF phenotype in stromal cells in the surrounding microenvironment, hence leading to increased expression of pro-angiogenic factors in tumor (63). Of note, transfer of miRNA-125a from MSC-derived exosomes to ECs promoted angiogenesis, both in vitro and in vivo (64). The effect of tumor-derived exosomes on vascular remodeling may affect both tumor growth and metastasis. For instance, melanoma-derived exosomes can induce vascular leak at pre-metastatic sites and can also reprogramme bone marrow progenitors towards a pro-vasculogenic phenotype (4). 
Exosomes have been shown to contain different kinds of angiogenic factors; it is necessary to understand the exact contributions of these factors to cancer development.

Tumor immune escape. Currently available evidence indicates a dual role of exosomes in mediating crosstalk between immune cells and cancer cells. On the one hand, various immunestimulatory genes, such as mesothelin, and carcinoembryonic antigen (CEA), are packed in tumor-derived exosomes $(65,66)$. On the other hand, several recent studies suggested that the cancer cells utilized exosomes containing nucleic acids and proteins to enact an immune escape.

An earlier study showed that the dendritic cell (DC)-derived exosomes stimulated an antitumor immune response (67). However, recent research showed tumor-derived exosomes may aid in immune evasion by impairing differentiation and maturation of dendritic cells, which changed their role from effective antigen presenting cells into negative modulators of immune response (68-70).

Exosomes may also play a role in the biology of cytotoxic $\mathrm{T}$ cells and regulatory T cells. For instance, in nasopharyngeal carcinoma, tumor-derived exosomes impaired $\mathrm{T}$ cell proliferation, differentiation and cytokine secretion in vivo and in vitro. The effect appeared to be mediated via down-regulation of the MAPK1 and JAK/STAT pathways by exosomal miRNAs (71). Clayton et al demonstrated an exosome-mediated mechanism that skewed the IL-2 responsiveness in favor of regulatory $\mathrm{T}$ cells and away from cytotoxic cells; this coordinated effect on cellular immunity strongly implicates the role of tumorderived exosomes in immune escape by tumor cells (72).

Tumor-associated macrophages (TAMs) are currently the most widely studied inflammatory cell component of tumor microenvironment (TME) and may also be activated by tumorderived exosomes. For instance, Fabbri et al identified a new mechanism of communication between TAMs and cancer cells via exosomal miRNAs. Specifically, exosomal miRNA-21 and miRNA-29a were recruited in the TME by TAMs and bind to their Toll-like receptor 8, triggering the Nuclear factor kappalight-chain-enhancer of activated B cells $(\mathrm{NF}-\kappa \mathrm{B})$ pathway and the secretion of interleukin-6 (IL-6) (73).

Moreover, exosomes derived from human prostate cancer cells were shown to express ligands for NKG2D, which induced downregulation of NKG2D in NK cells and impaired NK cell cytotoxic function (74). Ying et al demonstrated that ovarian tumor-derived exosomes play a crucial role in regulating the polarization of tumor-promoting M2 macrophages (75).

While the above examples demonstrate that tumor-derived exosomes may suppress the immune response, it appears that exosomes derived from immune cells can also influence the cancer cells. For instance, exosomes from activated $\mathrm{CD}^{+}$ $\mathrm{T}$ cells increased tumor immunogenicity by activating ERK and $N F-\kappa B$ signaling, which can promote the metastatic potential of tumor cells (76). Collectively, these studies suggest that exosomes may mediate immunosuppression in tumor-bearing host in different ways.

Drug resistance. Drug resistance has long been a major obstacle in the management of cancers. Recently, exosomes are of great interest in drug resistance studies. Drug-resistant cancer cells may spread resistance to hitherto sensitive ones by releasing exosomes; such effects could be partly attributed to the intercellular transfer of specific proteins, miRNAs, and even long noncoding RNAs (77-80).

Stromal cells were found to initiate cross-talk with cancer cells via exosomes. CAF-derived exosomes were shown to contribute to proliferation and chemoresistance of pancreatic cancer cells (81). Boelens et al demonstrated the transfer of exosomes from stromal cells to breast cancer cells activated antiviral retinoic acid-inducible gene 1 enzyme (RIG-1) signaling to regulate the expansion of therapy-resistant tumorinitiating cells (82). Further study by Au Yeung et al showed that in ovarian cancer, exosomal transportation of CAF-derived miRNA-21 conferred paclitaxel resistance in ovarian cancer cells through targeting APAF1 (49). Moreover, a recent study by Sun et al demonstrated that suppression of miRNA122 resulted in taxol resistance by upregulating Septin-9 in HCC (29). Qu et al reported that exosome-transmitted LncRNA promoted Sunitinib resistance in renal cancer by acting as a competing endogenous RNA for miRNA-34 and miRNA-449 to promote AXL and c-MET expression (79).

In addition, exosomes may also affect tumor chemotherapy by mediating drug efflux. Shedden et al found that doxorubicin can be encapsulated and exported by tumor-derived exosomes (83). Moreover, exosomes may play a role in lowering the therapeutic effect of antibodies by modulating their binding to cancer cells. For instance, breast cancer cellderived exosomes were shown to have a high expression of HER2 which interfered with the activity of the monoclonal antibody trastuzumab in vitro (84). Collectively, exosomes derived from both cancer cells and stromal cells can contribute to the development of chemoresistance in tumor cells.

Metastasis. Exosomes not only affect cells in the location where they are produced, but may also influence cells in distant tissues. Exosomes are involved in both the initiation of metastasis and the preparation of a pre-metastatic niche. Exosomes may assist cancer cells in acquiring migratory and invasive properties through EMT. For instance, Aga et al demonstrated that treatment of EBV-negative cells with LMP1-exosomes increases migration and invasiveness of nasopharyngeal cancer cells in functional assays, which correlates with the phenotype associated with EMT (85). Recently, an in vitro imaging experiment also showed the importance of exosomemediated exchange of molecules for metastasis among tumor cells (38).

The pre-metastatic niche is a prerequisite of tumor metastasis. Exosomes derived from the primary tumor can act as potential mediators for priming the pre-metastatic niche. Pancreatic tumor-derived exosomes enriched in macrophage migration inhibitory factors recruited macrophages to establish pre-metastatic niche in the liver, which resulted in increased hepatic macrometastatic burden (86). Moreover, breast cancer cell-derived exosomal miRNA-122 was shown to suppress glucose uptake by niche cells to promote metastasis, both in vitro and in vivo (3). Liu et al recently reported the Toll-like receptor 3 (TLR3) mediated crosstalk between pulmonary epithelial cells and tumor exosomal RNAs as being critical to the initiation of neutrophil recruitment and lung metastatic niche formation (87). In addition, tumor-derived exosomes were shown to express unique 
integrins which prepare the pre-metastatic niche by fusing with resident cells and by activating Src phosphorylation and pro-inflammatory S100 expression at the eventual site of metastasis (88).

Recently, Bliss et al reported the nature of regulatory interactions between breast cancer cells and MSC mediated by exosomes and MSC-derived exosomes may stimulate cycling quiescence and early breast cancer dormancy in bone marrow (89). Moreover, tumor-derived exosomes carrying miRNA-181c may trigger the breakdown of blood-brain-barrier (BBB) to promote brain metastasis (90). Zhang et al demonstrated that astrocyte-derived exosomes mediate intercellular transfer of PTEN-targeting miRNAs to metastatic tumor cells, which results in PTEN silencing in these tumor cells. This loss of PTEN expression leads to increased chemokine CCL2 level that recruits myeloid cells to reciprocally promote brain metastasis (91). These findings show that the intercellular crosstalk mediated by exosomes is a crucial mechanism for tumor metastasis.

\section{Exosomes as cancer biomarkers}

Exosomes have been detected in nearly all kinds of body fluids, including blood, urine, saliva, amniotic fluid, cerebrospinal fluids, bile, ascites, tears, breast milk and semen (9,92-96). Almost all types of cells can secrete exosomes containing specific proteins, lipids, RNA and even DNA into their microenvironment and circulation (97).

The discovery of elevated level of exosomal miRNAs in the plasma of certain cancer patients was the first indication of the potential use of circulating exosomes as cancer biomarkers. Taylor et al reported that circulating exosomal miRNAs from patients with ovarian cancer were significantly distinct from profiles observed in benign disease and healthy volunteers (98). Microarray analyses of miRNAs derived from circulating exosomes derived from 88 patients with primary colorectal cancer (CRC) and 11 healthy donors, revealed significantly higher levels of 7 miRNAs in the former (99). Recently, Zhu et al demonstrated that the levels of miRNA19a-3p, miRNA-21-5p and miRNA-425-5p were significantly elevated in exosomes from colorectal cancer patients' serum samples (100).

In addition, Li et al reported that LncRNA can be detected in plasma, and one of the possible mechanisms of its stable existence in blood was its protection by exosomes (101). Li et al recently reported that high levels of exosomal circular RNAs (circRNAs) and serum exosomal circRNAs can distinguish cancer patients from healthy individuals (102).

Proteins associated with tumor-derived exosomes are also seen as potential biomarkers. Exosomes double-positive for CD63 or caveolin- 1 and Rab-5b were significantly increased in plasma from melanoma patients as compared to that from healthy donors (103). Noteworthy, Melo et al showed that Glypican-1-positive circulating exosomes was a reliable biomarker for early detection of pancreatic cancer, with superior prognostic value than CA19-9 (104). Similarly, in a study by Lea et al provided proof-of-concept data that supported the high diagnostic power of phosphatidylserine-positive exosomes detected in the blood of women with ovarian malignancies (105).
For prognostic evaluation, circulating exosomes may enhance the stratification of cancer patients with high-risk factors. Manier et al reported that two circulating exosomal miRNAs, namely let-7b and miRNA-18a, improved survival prediction in patients with multiple myeloma (106). Similar results have been found in multiple types of cancers, including non-small cell lung cancer, esophageal squamous cell carcinoma, colorectal cancer, HCC and nasopharyngeal carcinoma (107-112).

For monitoring treatment response, exosomes have been demonstrated to accurately reflect the levels of proteins and mRNAs in parental cells throughout treatment and therefore can serve as potential biomarker of chemotherapy response $(113,114)$. Skog et al identified a protein signature in circulating exosomes linked with clinical stages of melanoma patients. As a predictor of TKI treatment response, exosomal EGFRvIII splice variant was detectable in the serum of glioblastoma multiforme patients, but not the 30 matched controls (53).

Additionally, some newly developed technologies exist to sort and enrich exosomes. Wunsch et al recently demonstrated that nanoscale deterministic lateral displacement pillar arrays, an efficient technology to sort exosomes, may open up the potential for on-chip separation and diagnosis (115).

Collectively, the development of exosome-based novel biomarkers may provide benefits to cancer patients in a wide variety of ways (Table I).

\section{Exosomes as cancer therapeutic targets}

Thus far, not much progress has been made in the use of exosomes as therapeutic agents in clinical practice. However, their importance in carcinogenesis envisages their use in individualized cancer therapeutics in the future.

First, complete depletion of circulating exosomes may potentially result in major benefit for cancer patients. Ciravolo et al reported that exosomes purified from HER2-positive early-stage breast cancer patient sera and HER2-overexpressing breast cancer cells can inhibit trastuzumab-induced anti-proliferative activity (84). Removal of such exosomes from advanced breast cancer patients is likely to improve response to trastuzumab therapy (116). Next, dendritic cell-derived exosomes have been used as tumor vaccine to trigger host antitumor immune response and inhibit cell growth and proliferation. Phase I clinical trials of dendritic exosomes in patients with metastatic melanoma and advanced non-small cell lung cancer have shown modest therapeutic effects $(117,118)$.

Exosomes may serve as delivery vehicle. Use of exosomes as nanocarriers for therapeutic agents is being actively explored. For instance, Alcarez et al demonstrated the use of exosomes for targeted delivery of siRNA after systemic administration, which indicates their potential use as vehicle for gene therapies (22). Tian et al reported that exosomes modified by targeting ligands can be used for delivery of doxorubicin to tumor cells (119). Kim et al reported good efficacy of an exosome-based system as a delivery vehicle for PTX to multi-drug resistant cancer cells (120).

More recently, MSC-derived exosomes are being examined for their role in MSC-based cellular therapy. For instance, Katakowski et al demonstrated that exosomes from 
Table I. Exosomes from distinct body fluids of cancer patients as biomarkers.

\begin{tabular}{|c|c|c|c|c|}
\hline Exosomal cargos & Cancer types & Clinical value & Biofluids & Refs. \\
\hline Phosphatidylserine & Ovarian cancer & $\begin{array}{l}\text { Elevated level of phosphatidylserine positive exosomes } \\
\text { in ovarian cancer patients than healthy controls }\end{array}$ & Plasma & (108) \\
\hline TRPC5 & Breast cancer & $\begin{array}{l}\text { Elevated level of exosomal TRPC5 in cancer patients } \\
\text { and higher levels may predict poorer progress }\end{array}$ & Plasma & (124) \\
\hline miRNA-1246, 21 & Breast cancer & $\begin{array}{l}\text { Elevated levels of these two exosomal miRNAs in } \\
\text { breast cancer patients than healthy controls }\end{array}$ & Plasma & (125) \\
\hline CRNDE-h & Colorectal cancer & $\begin{array}{l}\text { Elevated level of exosomal CRNDE-h in cancer patients } \\
\text { and higher levels predict poorer progress }\end{array}$ & Serum & (110) \\
\hline miRNA-4772-3p & Colon cancer & $\begin{array}{l}\text { Lower level of exosomal miRNA- } 4772-3 p \text { predict } \\
\text { tumor recurrence }\end{array}$ & Serum & (126) \\
\hline $\begin{array}{l}\text { miRNA-19a-3p } \\
21-5 p, 425-5 p\end{array}$ & Colorectal cancer & $\begin{array}{l}\text { Elevated levels of the three exosomal miRNAs in } \\
\text { colorectal cancer patients than healthy controls }\end{array}$ & Serum & $(100)$ \\
\hline miRNA-17-92a & Colorectal cancer & $\begin{array}{l}\text { Elevated level in colorectal cancer patients and higher } \\
\text { levels may predict poorer progress }\end{array}$ & Serum & (127) \\
\hline $\begin{array}{l}\text { miRNA-19-3p } \\
21-5 p, 221-3 p\end{array}$ & $\begin{array}{l}\text { Lung } \\
\text { adenocarcinoma }\end{array}$ & $\begin{array}{l}\text { Elevated levels of the three miRNAs in lung } \\
\text { adenocarcinoma patients than healthy controls }\end{array}$ & Plasma & (128) \\
\hline $\begin{array}{l}\text { miRNA-302a, } \\
302-c, 126\end{array}$ & $\begin{array}{l}\text { Non-small cell lung } \\
\text { cancer (NSCLC) }\end{array}$ & $\begin{array}{l}\text { Elevated levels of the three miRNAs in NSCLC } \\
\text { patients than healthy controls }\end{array}$ & $\begin{array}{l}\text { Plasma/ } \\
\text { Broncho- } \\
\text { alveolar lavage }\end{array}$ & $(129)$ \\
\hline $\begin{array}{l}\text { EML4-ALK } \\
\text { fushion }\end{array}$ & NSCLC & $\begin{array}{l}\text { EML4-ALK fushion transcripts have been identified } \\
\text { in the exosomal RNA of NSCLC patients }\end{array}$ & Plasma & (130) \\
\hline Glypican-1 & Pancreatic cancer & $\begin{array}{l}\text { Higher level of Glypican-1 positive exosomes } \\
\text { in patients with early- and late-stage pancreatic } \\
\text { cancer than healthy controls }\end{array}$ & Serum & (107) \\
\hline $\begin{array}{l}\text { miRNA-1246, } \\
4644,3976,4306\end{array}$ & Pancreatic cancer & $\begin{array}{l}\text { Elevated levels of these } 4 \text { exosomal miRNAs in } \\
\text { pancreatic cancer patients compared to healthy controls }\end{array}$ & Serum & (131) \\
\hline LncRNA-p21 & Prostate cancer & $\begin{array}{l}\text { Elevated level of exosomal lncRNA-p } 21 \text { in patients } \\
\text { with prostate cancer than healthy controls }\end{array}$ & Plasma & $(132)$ \\
\hline miRNA-21, 375 & Prostate cancer & $\begin{array}{l}\text { Elevated levels of urinary exosomal miRNA- } 21 \text { and } \\
\text { miRNA- } 375 \text { in patients with prostate cancer than } \\
\text { healthy controls }\end{array}$ & Urine & (133) \\
\hline $\begin{array}{l}\text { miRNA-375, } \\
1290\end{array}$ & Prostate cancer & $\begin{array}{l}\text { Castration-resident prostate cancer patients with elevated } \\
\text { levels of both exosomal miRNA- } 375 \text { and miRNA-1290 } \\
\text { may predict poorer progress }\end{array}$ & Serum & (134) \\
\hline miRNA-718 & $\mathrm{HCC}$ & $\begin{array}{l}\text { Lower level of exosomal miRNA- } 718 \text { in patients } \\
\text { with HCC patients with recurrence after liver } \\
\text { transplantation than those without recurrence }\end{array}$ & Serum & $(135)$ \\
\hline miRNA-21 & $\mathrm{HCC}$ & $\begin{array}{l}\text { Elevated level of exosomal mircroRNA- } 21 \text { in } \mathrm{HCC} \\
\text { cancer patients than healthy controls }\end{array}$ & Serum & (136) \\
\hline $\begin{array}{l}\text { miRNA-211, } \\
222,224\end{array}$ & $\mathrm{HCC}$ & $\begin{array}{l}\text { Elevated levels of these three exosomal mircroRNAs in } \\
\text { HCC cancer patients than healthy controls }\end{array}$ & Serum & (137) \\
\hline CD34 & $\begin{array}{l}\text { Acute myeloid } \\
\text { leukemia (AML) }\end{array}$ & $\begin{array}{l}\text { Higher level of CD } 34 \text { positive exosomes in AML patients } \\
\text { than healthy control }\end{array}$ & Plasma & $(138)$ \\
\hline $\begin{array}{l}\text { Let-7b, } \\
\text { miRNA-18a }\end{array}$ & MM & $\begin{array}{l}\text { Elevated expression in cancer patients and higher levels of } \\
\text { these two exosomal miRNAs may predict poorer progress }\end{array}$ & Serum & (106) \\
\hline
\end{tabular}

MSCs expressing miRNA-146b significantly reduced glioma xenograft growth in rat model of primary brain tumor (121). Similarly, a study reported by Ono et al suggested that exosomal transfer of miRNAs from MSCs may promote breast cancer dormancy in a metastatic niche (122). Additionally, use of exosomes derived from BM-MSCs as nanocarriers for targeted delivery of antitumor drugs such as paclitaxel (PTX) has also been investigated (123). 


\section{Conclusion}

The rapid increase in the number of published studies, especially in oncology, clearly reflects the enthusiasm on research of exosome biology and function. Cancer cells communicate with surrounding and distant cells via exosomes. Exosomes constitute a bi-directional interaction network that mediates the intercellular cross talk between cancer cells and the microcellular environment to promote cancer development, progression, metastasis, and drug resistance. However, most pieces of the aforementioned findings are gathered from cell culture experiments. Therefore, it is vital to substantiate these results in more rigorous in vitro settings. Moreover, exosomes released by cancer cells and TME are highly heterogeneous. But there are few reports explaining the role of each of these subtypes. The difficulties in elucidating the roles of specific exosomes include lack of unique molecules to distinguish each exosome subtype and appropriate exosomes isolation methods. Future technical advances may lead to significant progress in the understanding of the heterogeneity of exosomes.

Exosomes have been proven to be stable carriers of genetic materials, and been nominated as promising tumor biomarkers for cancer diagnosis and prognosis. Moreover, during cancer treatment, exosomes may switch their contents and may therefore exhibit traits for the monitoring of therapeutic efficiency. Furthermore, as vectors for drugs and tumor vaccines, exosome-based delivery is rigorously evaluated as an emerging therapeutic strategy for cancer. Additional studies are much needed to better elucidate their role and mechanism of action in cancer to reduce the risk of off-target effects and therapeutic failures. The several aforementioned results still require further validation in clinical settings, especially in independent prospective cohorts.

Altogether, with the emergence of precision medicine, future studies on exosomes should not only emphasize their roles in cancer biology, but may also open new avenues for cancer diagnostics and therapeutics.

\section{Acknowledgements}

This work was supported by the National Natural Science Foundation of China (81372359), the National High Technology Research and Development Program of China (2015AA020106), The National Key Research and Development Program of China (2016YFC1303201, 2016YFC0905400), and the Institutional Fundamental Research Funds (JK2014B14, NCC2016YKY-06).

\section{References}

1. Trams EG, Lauter CJ, Salem N Jr and Heine U: Exfoliation of membrane ecto-enzymes in the form of micro-vesicles. Biochim Biophys Acta 645: 63-70, 1981

2. Harding C, Heuser J and Stahl P: Receptor-mediated endocytosis of transferrin and recycling of the transferrin receptor in rat reticulocytes. J Cell Biol 97: 329-339, 1983.

3. Fong MY, Zhou W, Liu L, Alontaga AY, Chandra M, Ashby J, Chow A, O'Connor ST, Li S, Chin AR, et al: Breastcancer-secreted miR-122 reprograms glucose metabolism in premetastatic niche to promote metastasis. Nat Cell Biol 17: 183-194, 2015.
4. Peinado H, Aleckovic M, Lavotshkin S, Matei I, Costa-Silva B, Moreno-Bueno G, Hergueta-Redondo M, Williams C, GarcíaSantos G, Ghajar CM, et al: Melanoma exosomes educate bone marrow progenitor cells toward a pro-metastatic phenotype through MET. Nat Med 18: 883-891, 2012.

5. Li J, Liu K, Liu Y, Xu Y, Zhang F, Yang H, Liu J, Pan T, Chen J, Wu M, et al: Exosomes mediate the cell-to-cell transmission of IFN-[alpha]-induced antiviral activity. Nat Immunol 14: 793-803, 2013.

6. Colombo M, Raposo G and Thery C: Biogenesis, secretion, and intercellular interactions of exosomes and other extracellular vesicles. Annu Rev Cell Dev Biol 30: 255-289, 2014.

7. Tkach $\mathrm{M}$ and Thery $\mathrm{C}$ : Communication by extracellular vesicles: Where we are and where we need to go. Cell 164: 1226-1232, 2016.

8. Schorey JS and Harding CV: Extracellular vesicles and infectious diseases: New complexity to an old story. J Clin Invest 126: 1181-1189, 2016.

9. Zhang X, Yuan X, Shi H, Wu L, Qian H and Xu W: Exosomes in cancer: Small particle, big player. J Hematol Oncol 8: 83, 2015.

10. Kalluri R: The biology and function of exosomes in cancer. J Clin Invest 126: 1208-1215, 2016.

11. Williams RL and Urbé S: The emerging shape of the ESCRT machinery. Nat Rev Mol Cell Biol 8: 355-368, 2007.

12. Trajkovic K, Hsu C, Chiantia S, Rajendran L, Wenzel D, Wieland F, Schwille P, Brugger B and Simons M: Ceramide triggers budding of exosome vesicles into multivesicular endosomes. Science 319: 1244-1247, 2008.

13. Robbins PD and Morelli AE: Regulation of immune responses by extracellular vesicles. Nat Rev Immunol 14: 195-208, 2014.

14. Baietti MF, Zhang Z, Mortier E, Melchior A, Degeest G, Geeraerts A, Ivarsson Y, Depoortere F, Coomans C, Vermeiren E, et al: Syndecan-syntenin-ALIX regulates the biogenesis of exosomes. Nat Cell Biol 14: 677-685, 2012.

15. Ostrowski M, Carmo NB, Krumeich S, Fanget I, Raposo G Savina A, Moita CF, Schauer K, Hume AN, Freitas RP, et al: Rab27a and Rab27b control different steps of the exosome secretion pathway. Nat Cell Biol 12: 19-30, 2010.

16. Fader CM, Sánchez DG, Mestre MB and Colombo MI: TI-VAMP/ VAMP7 and VAMP3/cellubrevin: Two v-SNARE proteins involved in specific steps of the autophagy/multivesicular body pathways. Biochim Biophys Acta 1793: 1901-1916, 2009.

17. Yu X, Harris SL and Levine AJ: The regulation of exosome secretion: A novel function of the p53 protein. Cancer Res 66: 4795-4801, 2006.

18. Lespagnol A, Duflaut D, Beekman C, Blanc L, Fiucci G, Marine J-C, Vidal M, Amson R and Telerman A: Exosome secretion, including the DNA damage-induced p53-dependent secretory pathway, is severely compromised in TSAP6/ Steap3-null mice. Cell Death Differ 15: 1723-1733, 2008.

19. Wei Y, Wang D, Jin F, Bian Z, Li L, Liang H, Li M, Shi L, Pan C, Zhu D, et al: Pyruvate kinase type M2 promotes tumour cell exosome release via phosphorylating synaptosome-associated protein 23. Nat Commun 8: 14041, 2017.

20. Savina A, Furlán M, Vidal M and Colombo MI: Exosome release is regulated by a calcium-dependent mechanism in K562 cells. J Biol Chem 278: 20083-20090, 2003.

21. Parolini I, Federici C, Raggi C, Lugini L, Palleschi S, De Milito A, Coscia C, Iessi E, Logozzi M, Molinari A, et al: Microenvironmental $\mathrm{pH}$ is a key factor for exosome traffic in tumor cells. J Biol Chem 284: 34211-34222, 2009.

22. Alvarez-Erviti L, Seow Y, Yin H, Betts C, Lakhal S and Wood MJ: Delivery of siRNA to the mouse brain by systemic injection of targeted exosomes. Nat Biotechnol 29: 341-345, 2011.

23. Morelli AE, Larregina AT, Shufesky WJ, Sullivan ML, Stolz DB, Papworth GD, Zahorchak AF, Logar AJ, Wang Z, Watkins SC et al: Endocytosis, intracellular sorting, and processing of exosomes by dendritic cells. Blood 104: 3257-3266, 2004.

24. Escrevente C, Keller S, Altevogt P and Costa J: Interaction and uptake of exosomes by ovarian cancer cells. BMC Cancer 11: 108, 2011.

25. Feng D, Zhao WL, Ye YY, Bai X-C, Liu R-Q, Chang L-F, Zhou Q and Sui S-F: Cellular internalization of exosomes occurs through phagocytosis. Traffic 11: 675-687, 2010.

26. Fitzner D, Schnaars M, van Rossum D, Krishnamoorthy G, Dibaj P, Bakhti M, Regen T, Hanisch U-K and Simons M: Selective transfer of exosomes from oligodendrocytes to microglia by macropinocytosis. J Cell Sci 124: 447-458, 2011. 
27. Glebov OO, Bright NA and Nichols BJ: Flotillin-1 defines a clathrin-independent endocytic pathway in mammalian cells. Nat Cell Biol 8: 46-54, 2006.

28. Otto GP and Nichols BJ: The roles of flotillin microdomainsendocytosis and beyond. J Cell Sci 124: 3933-3940, 2011.

29. Sun H-L, Cui R, Zhou J, Teng K, Hsiao Y-H, Nakanishi K, Fassan M, Luo Z, Shi G, Tili E, et al: ERK activation globally downregulates miRNAs through phosphorylating exportin-5. Cancer Cell 30: 723-736, 2016.

30. Kowal J, Tkach M and Thery C: Biogenesis and secretion of exosomes. Curr Opin Cell Biol 29: 116-125, 2014.

31. Gutiérrez-Vázquez C, Villarroya-Beltri C, Mittelbrunn M and Sánchez-Madrid F: Transfer of extracellular vesicles during immune cell-cell interactions. Immunol Rev 251: 125-142, 2013.

32. Wood SL, Knowles MA, Thompson D, Selby PJ and Banks RE: Proteomic studies of urinary biomarkers for prostate, bladder and kidney cancers. Nat Rev Urol 10: 206-218, 2013.

33. Subra C, Laulagnier K, Perret B and Record M: Exosome lipidomics unravels lipid sorting at the level of multivesicular bodies. Biochimie 89: 205-212, 2007.

34. Valadi H, Ekström K, Bossios A, Sjöstrand M, Lee JJ and Lötvall JO: Exosome-mediated transfer of mRNAs and microRNAs is a novel mechanism of genetic exchange between cells. Nat Cell Biol 9: 654-659, 2007.

35. Melo SA, Sugimoto H, O'Connell JT, Kato N, Villanueva A, Vidal A, Qiu L, Vitkin E, Perelman LT, Melo CA, et al: Cancer exosomes perform cell-independent microRNA biogenesis and promote tumorigenesis. Cancer Cell 26: 707-721, 2014.

36. Crescitelli R, Lässer C, Szabó TG, Kittel A, Eldh M, Dianzani I, Buzás EI and Lötvall J: Distinct RNA profiles in subpopulations of extracellular vesicles: Apoptotic bodies, microvesicles and exosomes. J Extracell Vesicles 2: eCollection, 2013. doi: 10.3402/ jev.v2i0.20677.

37. Le MT, Hamar P, Guo C, Basar E, Perdigão-Henriques R, Balaj L and Lieberman J: miR-200-containing extracellular vesicles promote breast cancer cell metastasis. J Clin Invest 124: 5109-5128, 2014

38. Zomer A, Maynard C, Verweij FJ, Kamermans A, Schäfer R, Beerling E, Schiffelers RM, de Wit E, Berenguer J, Ellenbroek SI et al: In vivo imaging reveals extracellular vesicle-mediated phenocopying of metastatic behavior. Cell 161: 1046-1057, 2015.

39. Donnarumma E, Fiore D, Nappa M, Roscigno G, Adamo A, Iaboni M, Russo V, Affinito A, Puoti I, Quintavalle C, et al: Cancer-associated fibroblasts release exosomal microRNAs that dictate an aggressive phenotype in breast cancer. Oncotarget 8: 19592-19608, 2017

40. Luga V, Zhang L, Viloria-Petit AM, Ogunjimi AA, Inanlou MR, Chiu E, Buchanan M, Hosein AN, Basik M and Wrana JL: Exosomes mediate stromal mobilization of autocrine Wnt-PCP signaling in breast cancer cell migration. Cell 151: 1542-1556, 2012.

41. Webber JP, Spary LK, Sanders AJ, Chowdhury R, Jiang WG, Steadman R, Wymant J, Jones AT, Kynaston H, Mason MD, et al: Differentiation of tumour-promoting stromal myofibroblasts by cancer exosomes. Oncogene 34: 290-302, 2015.

42. Hoshino D, Kirkbride KC, Costello K, Clark ES, Sinha S, GregaLarson N, Tyska MJ and Weaver AM: Exosome secretion is enhanced by invadopodia and drives invasive behavior. Cell Rep 5: 1159-1168, 2013.

43. Lazar I, Clement E, Dauvillier S, Milhas D, Ducoux-Petit M LeGonidec S, Moro C, Soldan V, Dalle S, Balor S, et al: Adipocyte exosomes promote melanoma aggressiveness through fatty acid oxidation: A novel mechanism linking obesity and cancer. Cancer Res 76: 4051-4057, 2016.

44. Al-Nedawi K, Meehan B, Micallef J, Lhotak V, May L, Guha A and Rak J: Intercellular transfer of the oncogenic receptor EGFRvIII by microvesicles derived from tumour cells. Nat Cell Biol 10: 619-624, 2008

45. Hong BS, Cho J-H, Kim H, Choi E-J, Rho S, Kim J, Kim J, Choi D-S, Kim Y-K, Hwang D, et al: Colorectal cancer cellderived microvesicles are enriched in cell cycle-related mRNAs that promote proliferation of endothelial cells. BMC Genomics 10: $556,2009$.

46. Kogure T, Lin WL, Yan IK, Braconi C and Patel T: Intercellular nanovesicle-mediated microRNA transfer: A mechanism of environmental modulation of hepatocellular cancer cell growth Hepatology 54: 1237-1248, 2011.

47. Zhu W, Huang L, Li Y, Zhang X, Gu J, Yan Y, Xu X, Wang M, Qian $\mathrm{H}$ and $\mathrm{Xu} \mathrm{W}$ : Exosomes derived from human bone marrow mesenchymal stem cells promote tumor growth in vivo. Cancer Lett 315: 28-37, 2012
48. Xiao H, Lässer C, Shelke GV, Wang J, Rådinger M, Lunavat TR, Malmhäll C, Lin LH, Li J, Li L, et al: Mast cell exosomes promote lung adenocarcinoma cell proliferation-role of KIT-stem cell factor signaling. Cell Commun Signal 12: 64, 2014

49. Au Yeung CL, Co NN, Tsuruga T, Yeung TL, Kwan SY, Leung CS, Li Y, Lu ES, Kwan K, Wong KK, et al: Exosomal transfer of stroma-derived miR21 confers paclitaxel resistance in ovarian cancer cells through targeting APAF1. Nat Commun 7: 11150,2016

50. Zhang Z, Li X, Sun W, Yue S, Yang J, Li J, Ma B, Wang J, Yang X, $\mathrm{Pu}$ M, et al: Loss of exosomal miR-320a from cancer-associated fibroblasts contributes to HCC proliferation and metastasis. Cancer Lett 397: 33-42, 2017.

51. Roccaro AM, Sacco A, Maiso P, Azab AK, Tai Y-T, Reagan M, Azab F, Flores LM, Campigotto F, Weller E, et al: BM mesenchymal stromal cell-derived exosomes facilitate multiple myeloma progression. J Clin Invest 123: 1542-1555, 2013.

52. Corthals SL, Jongen-Lavrencic M, de Knegt Y, Peeters JK, Beverloo HB, Lokhorst HM and Sonneveld P: Micro-RNA-15a and micro-RNA-16 expression and chromosome 13 deletions in multiple myeloma. Leuk Res 34: 677-681, 2010.

53. Skog J, Würdinger T, Van Rijn S, Meijer DH, Gainche L, Curry WT, Carter BS, Krichevsky AM and Breakefield XO: Glioblastoma microvesicles transport RNA and proteins that promote tumour growth and provide diagnostic biomarkers. Nat Cell Biol 10: 1470-1476, 2008.

54. Taverna S, Flugy A, Saieva L, Kohn EC, Santoro A, Meraviglia S, De Leo $G$ and Alessandro R: Role of exosomes released by chronic myelogenous leukemia cells in angiogenesis. Int J Cancer 130: 2033-2043, 2012.

55. Hood JL, Pan H, Lanza GM and Wickline SA: Paracrine induction of endothelium by tumor exosomes. Lab Invest 89: 1317-1328, 2009.

56. Millimaggi D, Mari M, D'Ascenzo S, Carosa E, Jannini EA, Zucker S, Carta G, Pavan A and Dolo V: Tumor vesicle-associated CD147 modulates the angiogenic capability of endothelial cells. Neoplasia 9: 349-357, 2007.

57. Wang J, De Veirman K, Faict S, Frassanito MA, Ribatti D, Vacca A and Menu E: Multiple myeloma exosomes establish a favourable bone marrow microenvironment with enhanced angiogenesis and immunosuppression. J Pathol 239: 162-173, 2016.

58. Gopal SK, Greening DW, Hanssen EG, Zhu H-J, Simpson RJ and Mathias RA: Oncogenic epithelial cell-derived exosomes containing Racl and PAK2 induce angiogenesis in recipient endothelial cells. Oncotarget 7: 19709-19722, 2016.

59. Vader P, Breakefield XO and Wood MJ: Extracellular vesicles: Emerging targets for cancer therapy. Trends Mol Med 20: 385-393, 2014

60. Kosaka N, Iguchi H, Hagiwara K, Yoshioka Y, Takeshita F and Ochiya T: Neutral sphingomyelinase 2 (nSMase2)-dependent exosomal transfer of angiogenic microRNAs regulate cancer cell metastasis. J Biol Chem 288: 10849-10859, 2013.

61. Fan G-C: Hypoxic exosomes promote angiogenesis. Blood 124: 3669-3670, 2014

62. Tadokoro H, Umezu T, Ohyashiki K, Hirano T and Ohyashiki JH: Exosomes derived from hypoxic leukemia cells enhance tube formation in endothelial cells. J Biol Chem 288: 34343-34351, 2013.

63. Kosaka N: Decoding the secret of cancer by means of extracellular vesicles. J Clin Med 5: 22, 2016.

64. Liang X, Zhang L, Wang S, Han Q and Zhao RC: Exosomes secreted by mesenchymal stem cells promote endothelial cell angiogenesis by transferring miR-125a. J Cell Sci 129: 2182-2189, 2016.

65. Andre F, Schartz NE, Movassagh M, Flament C, Pautier P, Morice P, Pomel C, Lhomme C, Escudier B, Le Chevalier T, et al: Malignant effusions and immunogenic tumour-derived exosomes. Lancet 360: 295-305, 2002.

66. Dai S, Wan T, Wang B, Zhou X, Xiu F, Chen T, Wu Y and Cao X: More efficient induction of HLA-A* 0201-restricted and carcinoembryonic antigen (CEA)-specific CTL response by immunization with exosomes prepared from heat-stressed CEA-positive tumor cells. Clin Cancer Res 11: 7554-7563, 2005.

67. Zitvogel L, Regnault A, Lozier A, Wolfers J, Flament C, Tenza D, Ricciardi-Castagnoli P, Raposo G and Amigorena S: Eradication of established murine tumors using a novel cell-free vaccine: Dendritic cell derived exosomes. Nat Med 4: 594-600, 1998.

68. Condamine T and Gabrilovich DI: Molecular mechanisms regulating myeloid-derived suppressor cell differentiation and function. Trends Immunol 32: 19-25, 2011. 
69. Valenti R, Huber V, Filipazzi P, Pilla L, Sovena G, Villa A, Corbelli A, Fais S, Parmiani G and Rivoltini L: Human tumorreleased microvesicles promote the differentiation of myeloid cells with transforming growth factor- $\beta$-mediated suppressive activity on T lymphocytes. Cancer Res 66: 9290-9298, 2006

70. Yang C, Kim S-H, Bianco NR and Robbins PD: Tumor-derived exosomes confer antigen-specific immunosuppression in a murine delayed-type hypersensitivity model. PLoS One 6 : e22517, 2011.

71. Ye S, Li Z-L, Luo D, Huang B, Chen Y-S, Zhang X, Cui J, Zeng Y and Li J: Tumor-derived exosomes promote tumor progression and T-cell dysfunction through the regulation of enriched exosomal microRNAs in human nasopharyngeal carcinoma. Oncotarget 5: 5439-5452, 2014.

72. Clayton A, Mitchell JP, Court J, Mason MD and Tabi Z: Human tumor-derived exosomes selectively impair lymphocyte responses to interleukin-2. Cancer Res 67: 7458-7466, 2007.

73. Fabbri M, Paone A, Calore F, Galli R, Gaudio E, Santhanam R, Lovat F, Fadda P, Mao C, Nuovo GJ, et al: MicroRNAs bind to Toll-like receptors to induce prometastatic inflammatory response. Proc Natl Acad Sci USA 109: E2110-E2116, 2012.

74. Clayton A, Mitchell JP, Court J, Linnane S, Mason MD and Tabi Z: Human tumor-derived exosomes down-modulate NKG2D expression. J Immunol 180: 7249-7258, 2008.

75. Ying X, Wu Q, Wu X, Zhu Q, Wang X, Jiang L, Chen X and Wang X: Epithelial ovarian cancer-secreted exosomal miR222-3p induces polarization of tumor-associated macrophages Oncotarget 7: 43076-43087, 2016.

76. Cai Z, Yang F, Yu L, Yu Z, Jiang L, Wang Q, Yang Y, Wang L, Cao $\mathrm{X}$ and Wang J: Activated $\mathrm{T}$ cell exosomes promote tumo invasion via Fas signaling pathway. J Immunol 188: 5954-5961, 2012.

77. Chen W, Liu X, Lv M, Chen L, Zhao J, Zhong S, Ji M, Hu Q, Luo Z, Wu J, et al: Exosomes from drug-resistant breast cancer cells transmit chemoresistance by a horizontal transfer of microRNAs. PLoS One 9: e95240, 2014.

78. Wei Y, Lai X, Yu S, Chen S, Ma Y, Zhang Y, Li H, Zhu X, Yao L and Zhang J: Exosomal miR-221/222 enhances tamoxifen resistance in recipient ER-positive breast cancer cells. Breast Cancer Res Treat 147: 423-431, 2014.

79. Qu L, Ding J, Chen C, Wu Z-J, Liu B, Gao Y, Chen W, Liu F, Sun W, Li X-F, et al: Exosome-transmitted lncARSR promotes sunitinib resistance in renal cancer by acting as a competing endogenous RNA. Cancer Cell 29: 653-668, 2016.

80. Chen Y, Wang L, Zhu Y, Chen Z, Qi X, Jin L, Jin J, Hua D and Ma X: Breast cancer resistance protein (BCRP)-containing circulating microvesicles contribute to chemoresistance in breast cancer. Oncol Lett 10: 3742-3748, 2015.

81. Richards KE, Zeleniak AE, Fishel ML, Wu J, Littlepage LE and Hill R: Cancer-associated fibroblast exosomes regulate survival and proliferation of pancreatic cancer cells. Oncogene 36: 1770-1778, 2016

82. Boelens MC, Wu TJ, Nabet BY, Xu B, Qiu Y, Yoon T, Azzam DJ, Twyman-Saint Victor C, Wiemann BZ, Ishwaran $\mathrm{H}$, et al: Exosome transfer from stromal to breast cancer cells regulates therapy resistance pathways. Cell 159: 499-513, 2014.

83. Shedden K, Xie XT, Chandaroy P, Chang YT and Rosania GR: Expulsion of small molecules in vesicles shed by cancer cells association with gene expression and chemosensitivity profiles. Cancer Res 63: 4331-4337, 2003.

84. Ciravolo V, Huber V, Ghedini GC, Venturelli E, Bianchi F, Campiglio M, Morelli D, Villa A, Mina PD, Menard S, et al: Potential role of HER2-overexpressing exosomes in countering trastuzumab-based therapy. J Cell Physiol 227: 658-667, 2012.

85. Aga M, Bentz GL, Raffa S, Torrisi MR, Kondo S, Wakisaka N, Yoshizaki T, Pagano JS and Shackelford J: Exosomal HIF1a supports invasive potential of nasopharyngeal carcinoma-associated LMP1-positive exosomes. Oncogene 33: 4613-4622, 2014

86. Costa-Silva B, Aiello NM, Ocean AJ, Singh S, Zhang H Thakur BK, Becker A, Hoshino A, Mark MT, Molina H, et al: Pancreatic cancer exosomes initiate pre-metastatic niche formation in the liver. Nat Cell Biol 17: 816-826, 2015

87. Liu Y, Gu Y, Han Y, Zhang Q, Jiang Z, Zhang X, Huang B, $\mathrm{Xu} X$, Zheng $\mathrm{J}$ and Cao X: Tumor exosomal RNAs promote lung pre-metastatic niche formation by activating alveolar epithelial TLR3 to recruit neutrophils. Cancer Cell 30: 243-256, 2016.

88. Hoshino A, Costa-Silva B, Shen T-L, Rodrigues G, Hashimoto A, Tesic Mark M, Molina H, Kohsaka S, Di Giannatale A, Ceder S, et al: Tumour exosome integrins determine organotropic metastasis. Nature 527: 329-335, 2015.
89. Bliss SA, Sinha G, Sandiford OA, Williams LM, Engelberth DJ, Guiro K, Isenalumhe LL, Greco SJ, Ayer S, Bryan M, et al: Mesenchymal stem cell-derived exosomes stimulate cycling quiescence and early breast cancer dormancy in bone marrow. Cancer Res 76: 5832-5844, 2016.

90. Tominaga N, Kosaka N, Ono M, Katsuda T, Yoshioka Y, Tamura K, Lötvall J, Nakagama $\mathrm{H}$ and Ochiya T: Brain metastatic cancer cells release microRNA-181c-containing extracellular vesicles capable of destructing blood-brain barrier. Nat Commun 6: 6716, 2015.

91. Zhang L, Zhang S, Yao J, Lowery FJ, Zhang Q, Huang W-C, Li P, Li M, Wang X, Zhang C, et al: Microenvironment-induced PTEN loss by exosomal microRNA primes brain metastasis outgrowth. Nature 527: 100-104, 2015.

92. Raposo G and Stoorvogel W: Extracellular vesicles: Exosomes, microvesicles, and friends. J Cell Biol 200: 373-383, 2013.

93. Keller S, Ridinger J, Rupp AK, Janssen JW and Altevogt P Body fluid derived exosomes as a novel template for clinical diagnostics. J Transl Med 9: 86, 2011.

94. Pisitkun T, Shen R-F and Knepper MA: Identification and proteomic profiling of exosomes in human urine. Proc Natl Acad Sci USA 101: 13368-13373, 2004

95. Gallo A, Tandon M, Alevizos I and Illei GG: The majority of microRNAs detectable in serum and saliva is concentrated in exosomes. PLoS One 7: e30679, 2012.

96. Lau C, Kim Y, Chia D, Spielmann N, Eibl G, Elashoff D, Wei F, Lin Y-L, Moro A, Grogan T, et al: Role of pancreatic cancerderived exosomes in salivary biomarker development. J Biol Chem 288: 26888-26897, 2013.

97. Kosaka N, Yoshioka Y, Fujita Y and Ochiya T: Versatile roles of extracellular vesicles in cancer. J Clin Invest 126: 1163-1172, 2016.

98. Taylor DD and Gercel-Taylor C: MicroRNA signatures of tumor-derived exosomes as diagnostic biomarkers of ovarian cancer. Gynecol Oncol 110: 13-21, 2008

99. Ogata-Kawata H, Izumiya M, Kurioka D, Honma Y, Yamada Y, Furuta K, Gunji T, Ohta H, Okamoto H, Sonoda H, et al: Circulating exosomal microRNAs as biomarkers of colon cancer. PLoS One 9: e92921, 2014.

100.Zhu M, Huang Z, Zhu D, Zhou X, Shan X, Qi LW, Wu L, Cheng W, Zhu J, Zhang L, et al: A panel of microRNA signature in serum for colorectal cancer diagnosis. Oncotarget 8: 17081-17091 2017

101.Li Q, Shao Y, Zhang X, Zheng T, Miao M, Qin L, Wang B, Ye G, Xiao B and Guo J: Plasma long noncoding RNA protected by exosomes as a potential stable biomarker for gastric cancer. Tumour Biol 36: 2007-2012, 2015 .

102.Li Y, Zheng Q, Bao C, Li S, Guo W, Zhao J, Chen D, Gu J, He X and Huang S: Circular RNA is enriched and stable in exosomes: A promising biomarker for cancer diagnosis. Cell Res 25: 981-984, 2015

103.Logozzi M, De Milito A, Lugini L, Borghi M, Calabrò L, Spada M, Perdicchio M, Marino ML, Federici C, Iessi E, et al: High levels of exosomes expressing CD63 and caveolin-1 in plasma of melanoma patients. PLoS One 4: e5219, 2009.

104. Melo SA, Luecke LB, Kahlert C, Fernandez AF, Gammon ST, Kaye J, LeBleu VS, Mittendorf EA, Weitz J, Rahbari N, et al: Glypican-1 identifies cancer exosomes and detects early pancreatic cancer. Nature 523: 177-182, 2015.

105. Lea J, Sharma R, Yang F, Zhu H, Ward ES and Schroit AJ: Detection of phosphatidylserine-positive exosomes as a diagnostic marker for ovarian malignancies: A proof of concept study. Oncotarget 8: 14395-14407, 2017.

106. Manier S, Liu CJ, Avet-Loiseau H, Park J, Shi J, Campigotto F, Salem KZ, Huynh D, Glavey SV, Rivotto B, et al: Prognostic role of circulating exosomal miRNAs in multiple myeloma. Blood 129: 2429-2436, 2017.

107. Liu Q, Yu Z, Yuan S, Xie W, Li C, Hu Z, Xiang Y, Wu N, Wu L, Bai L, et al: Circulating exosomal microRNAs as prognostic biomarkers for non-small-cell lung cancer. Oncotarget 8: 13048-13058, 2017.

108. Matsumoto Y, Kano M, Akutsu Y, Hanari N, Hoshino I, Murakami K, Usui A, Suito H, Takahashi M, Otsuka R, et al: Quantification of plasma exosome is a potential prognostic marker for esophageal squamous cell carcinoma. Oncol Rep 36: 2535-2543, 2016

109. Sandfeld-Paulsen B, Aggerholm-Pedersen N, Baek R, Jakobsen KR, Meldgaard P, Folkersen BH, Rasmussen TR, Varming K, Jørgensen MM and Sorensen BS: Exosomal proteins as prognostic biomarkers in non-small cell lung cancer. Mol Oncol 10: 1595-1602, 2016 
110.Liu T, Zhang X, Gao S, Jing F, Yang Y, Du L, Zheng G, Li P, Li C and Wang C: Exosomal long noncoding RNA CRNDE-h as a novel serum-based biomarker for diagnosis and prognosis of colorectal cancer. Oncotarget 7: 85551-85563, 2016

111. Ye SB, Zhang H, Cai TT, Liu Y-N, Ni J-J, He J, Peng J-Y, Chen Q-Y, Mo H-Y, Cui-J, et al: Exosomal miR-24-3p impedes T-cell function by targeting FGF11 and serves as a potential prognostic biomarker for nasopharyngeal carcinoma. J Pathol 240: 329-340, 2016.

112. Wu Z, Zeng Q, Cao K and Sun Y: Exosomes: Small vesicles with big roles in hepatocellular carcinoma. Oncotarget 7: 60687-60697, 2016

113. Hegi ME, Diserens A-C, Gorlia T, Hamou M-F, de Tribolet N, Weller M, Kros JM, Hainfellner JA, Mason W, Mariani L, et al: MGMT gene silencing and benefit from temozolomide in glioblastoma. N Engl J Med 352: 997-1003, 2005.

114. Shao H, Chung J, Lee K, Balaj L, Min C, Carter BS, Hochberg FH, Breakefield XO, Lee $\mathrm{H}$ and Weissleder R: Chip-based analysis of exosomal mRNA mediating drug resistance in glioblastoma. Nat Commun 6: 6999, 2015.

115. Wunsch BH, Smith JT, Gifford SM, Wang C, Brink M, Bruce RL, Austin RH, Stolovitzky G and Astier Y: Nanoscale lateral displacement arrays for the separation of exosomes and colloids down to $20 \mathrm{~nm}$. Nat Nanotechnol 11: 936-940, 2016.

116. Marleau AM, Chen C-S, Joyce JA and Tullis RH: Exosome removal as a therapeutic adjuvant in cancer. J Transl Med 10: 134, 2012.

117. Morse MA, Garst J, Osada T, Khan S, Hobeika A, Clay TM, Valente N, Shreeniwas R, Sutton M, Delcayre A, et al: A phase I study of dexosome immunotherapy in patients with advanced non-small cell lung cancer. J Transl Med 3: 9, 2005

118. Escudier B, Dorval T, Chaput N, André F, Caby M-P, Novault S, Flament C, Leboulaire C, Borg C, Amigorena S, et al: Vaccination of metastatic melanoma patients with autologous dendritic cell (DC) derived-exosomes: Results of the first phase I clinical trial. J Transl Med 3: 10, 2005.

119. Tian Y, Li S, Song J, Ji T, Zhu M, Anderson GJ, Wei J and Nie G: A doxorubicin delivery platform using engineered natural membrane vesicle exosomes for targeted tumor therapy. Biomaterials 35: 2383-2390, 2014.

120. Kim MS, Haney MJ,Zhao Y, Mahajan V,Deygen I, Klyachko NL, Inskoe E, Piroyan A, Sokolsky M, Okolie O, et al: Development of exosome-encapsulated paclitaxel to overcome MDR in cancer cells. Nanomedicine (Lond) 12: 655-664, 2016.

121. Katakowski M, Buller B, Zheng X, Lu Y, Rogers T, Osobamiro O, Shu W, Jiang $\mathrm{F}$ and Chopp M: Exosomes from marrow stromal cells expressing miR-146b inhibit glioma growth. Cancer Lett 335: 201-204, 2013

122. Ono M, Kosaka N, Tominaga N, Yoshioka Y, Takeshita F, Takahashi R, Yoshida M, Tsuda H, Tamura K and Ochiya T: Exosomes from bone marrow mesenchymal stem cells contain a microRNA that promotes dormancy in metastatic breast cancer cells. Sci Signal 7: ra63, 2014.

123. Pascucci L, Coccè V, Bonomi A, Ami D, Ceccarelli P, Ciusani E, Viganò L, Locatelli A, Sisto F, Doglia SM, et al: Paclitaxel is incorporated by mesenchymal stromal cells and released in exosomes that inhibit in vitro tumor growth: A new approach for drug delivery. J Control Release 192: 262-270, 2014.

124. Wang T, Ning K, Lu TX, Sun X, Jin L, Qi X, Jin J and Hua D: Increasing circulating exosomes-carrying TRPC5 predicts chemoresistance in metastatic breast cancer patients. Cancer Sci 108: 448-454, 2017.
125. Hannafon BN, Trigoso YD, Calloway CL, Zhao YD, Lum DH, Welm AL, Zhao ZJ, Blick KE, Dooley WC and Ding WQ: Plasma exosome microRNAs are indicative of breast cancer. Breast Cancer Res 18: 90, 2016.

126. Liu C, Eng C, Shen J, Lu Y, Takata Y, Mehdizadeh A, Chang GJ, Rodriguez-Bigas MA, Li Y, Chang P, et al: Serum exosomal $\mathrm{miR}-4772-3 \mathrm{p}$ is a predictor of tumor recurrence in stage II and III colon cancer. Oncotarget 7: 76250-76260, 2016.

127. Matsumura T, Sugimachi K, Iinuma H, Takahashi Y, Kurashige J, Sawada G, Ueda M, Uchi R, Ueo H, Takano Y, et al: Exosomal microRNA in serum is a novel biomarker of recurrence in human colorectal cancer. Br J Cancer 113: 275-281, 2015.

128.Zhou X, Wen W, Shan X, Zhu W, Xu J, Guo R, Cheng W, Wang F, Qi LW, Chen Y, et al: A six-microRNA panel in plasma was identified as a potential biomarker for lung adenocarcinoma diagnosis. Oncotarget 8: 6513-6525, 2017.

129. Rodríguez M, Silva J, López-Alfonso A, López-Muñiz MB, Peña C, Domínguez G, García JM, López-Gónzalez A, Méndez M, Provencio M, et al: Different exosome cargo from plasma/bronchoalveolar lavage in non-small-cell lung cancer. Genes Chromosomes Cancer 53: 713-724, 2014.

130. Brinkmann K, Carbone DP, Enderle D, Koestler T, Bentink S, Emenegger J, Spiel A, Mueller R, O'Neill V, Skog J, et al: Exosomal RNA based liquid biopsy detection of EML4-ALK in plasma from NSCLC patients. In: Proc Int Assoc IALSC, Denver, CO, 2016.

131. Madhavan B, Yue S, Galli U, Rana S, Gross W, Müller M, Giese NA, Kalthoff H, Becker T, Büchler MW, et al: Combined evaluation of a panel of protein and miRNA serum-exosome biomarkers for pancreatic cancer diagnosis increases sensitivity and specificity. Int J Cancer 136: 2616-2627, 2015.

132. Işın M, Uysaler E, Özgür E, Köseoğlu H, Şanlı Ö, Yücel ÖB, Gezer U and Dalay N: Exosomal lncRNA-p21 levels may help to distinguish prostate cancer from benign disease. Front Genet 6: $168,2015$.

133. Huang Z, Zhang L, Zhu D, Shan X, Zhou X, Qi LW, Wu L, Zhu J, Cheng W, Zhang $\mathrm{H}$ et al: A novel serum microRNA signature to screen esophageal squamous cell carcinoma. Cancer Med 6: 109-119, 2017.

134. Mirzaei H, Fathullahzadeh S, Khanmohammadi R, Darijani M, Momeni F, Masoudifar A, Goodarzi M, Mardanshah O, Stanveng J, Jaafari MR, et al: State of the art in microRNA as diagnostic and therapeutic biomarkers in chronic lymphocytic leukemia. J Cell Physiol: Jan 13, 2017 (Epub ahead of print).

135. Sugimachi K, Matsumura T, Hirata H, Uchi R, Ueda M, Ueo H, Shinden Y, Iguchi T, Eguchi H, Shirabe K, et al: Identification of a bona fide microRNA biomarker in serum exosomes that predicts hepatocellular carcinoma recurrence after liver transplantation. Br J Cancer 112: 532-538, 2015.

136. Wang H, Hou L, Li A, Duan Y, Gao H and Song X: Expression of serum exosomal microRNA-21 in human hepatocellular carcinoma. Biomed Res Int 2014: 864894, 2014.

137. Sohn W, Kim J, Kang SH, Yang SR, Cho J-Y, Cho HC, Shim SG and Paik Y-H: Serum exosomal microRNAs as novel biomarkers for hepatocellular carcinoma. Exp Mol Med 47: e184, 2015.

138. Hong CS, Muller L, Boyiadzis M and Whiteside TL: Isolation and characterization of CD34 blast-derived exosomes in acute myeloid leukemia. PLoS One 9: e103310, 2014. 